\title{
Happiness and Air Pollution
}

\author{
Arik Levinson \\ Georgetown University Economics Department and NBER \\ Arik.Levinson@georgetown.edu
}

January 21, 2020

\begin{abstract}
I pose three questions: Does pollution make people unhappy? How much? And is the effect proportional to pollution's estimated effects on mortality and productivity? Answers to those three questions must overcome three obstacles: unobserved characteristics of locales correlated with both pollution and happiness; selection by pollution-averse individuals to less polluted areas; and habituation by residents to local circumstances. Since 2010, when the initial few studies relating happiness to pollution were last surveyed, thirty more have been published. I discuss how the new studies tackle each of those three problems and I devise a method of comparing their findings despite their different measures of both happiness and pollution. I combine the happiness and income coefficients from each study into a willingness-to-pay measure, for a one-day, one-standard-deviation pollution reduction. Finally, I document a surprising concordance between those calculated willingness-to-pay measures and new research assessing the effects of pollution on mortality and productivity.
\end{abstract}

Key Words: Stated well-being, willingness-to-pay, habituation, short-termism.

\section{Acknowledgments.}

This is a draft book chapter. The final version is available in Handbook on Wellbeing, Happiness and the Environment edited by David Maddison, Katrin Rehdanz and Heinz Welsch, published in 2020, Edward Elgar Publishing Ltd. The material cannot be used for any other purpose without further permission of the publisher, and is for private use only.

Kevin Ankney and Lina Yu provided especially helpful insights and research assistance. Chris Barrington-Leigh, Simon Luechinger, Mirko Moro, Katrin Rehdanz, and Heinz Welsch helped with thoughtful feedback on early drafts. Some of the material used here appeared in draft form in an earlier NBER working paper 19329 (Levinson, 2013). 


\section{Happiness and Air Pollution}

\section{Introduction}

Air pollution sickens people and sometimes kills them. It reduces workers' productivity, decreases students' test scores, damages buildings, and reduces property values. ${ }^{1}$ Given all these consequences, it may be obvious that air pollution also makes people less happy. And yet demonstrating the direct, cause-and-effect relationship between pollution and happiness is difficult. Researchers cannot merely ask a standard survey question about well-being or life satisfaction in polluted and clean places and then interpret the results as the effect of pollution on happiness. That won't work, for three reasons: omitted variables, selection, and habituation.

The first, omitted variable bias, involves a simple and ubiquitous statistical problem. Lots of things affect people's happiness, many of which are correlated with pollution. One example is income. Researchers and activists concerned about "environmental justice" have long observed that lower-income people live in more polluted places. And happiness researchers have long debated the degree to which income makes people happy. If poor people live in polluted places and income makes people happy, then people living with pollution may be less happy because they are poor rather than because of the local pollution. In this narrow example, the solution is simple: any estimate of the effect of pollution on people's happiness must control statistically for their incomes. But that leaves open the concern that other characteristics of people or the places they live may also be correlated with both pollution and happiness. Automobile traffic causes pollution and makes people unhappy. Homes near the ocean have cleaner air but may have happier occupants because of the beach access. Any successful estimate of the effect of pollution on happiness must control statistically for all of those possibilities - the ones we can see and measure and the ones we cannot.

The second problem, selection, involves a slightly more complex but still standard statistical problem. People choose where to live, and those who care the most about pollution presumably choose cleaner places. Survey respondents who have chosen polluted places might express no less happiness than respondents who chose less polluted places. They chose the polluted places because they care less about pollution. But that doesn't mean that increasing pollution in the clean places wouldn't make their residents less happy. The selection by people into polluted and unpolluted places may mask any true direct effect of pollution on happiness for a representative person.

The third problem, habituation, pertains especially to this topic. Graham (2009) summarizes evidence that people become inured to, or habituated to, things like poor health, crime, corruption, and democracy. That is, unhealthy people living in dangerous, corrupt, undemocratic places are not any less happy as a consequence, at least not in the long run. They become habituated to those problems. It makes sense that people might also become habituated

\footnotetext{
${ }^{1}$ See, for example OECD (2016), Neidell (2017), and Ebenstein et al. (2016).
} 
to pollution. People living in Los Angeles may be no less happy than comparable people living in Portland, even though the air pollution is worse in Los Angeles. Similarly, Los Angeles residents may be no happier today than their counterparts 40 years ago when the city's air was dirtier. They are habituated to better air quality than past Los Angeles residents and to worse air quality than current Portland residents.

There's a solution to all three problems — omitted variables, selection, and habituationbut it isn't easy. We need to examine differences in people's happiness in response to differences in pollution that are not correlated with other unobserved differences, are not the result of selection by the survey respondents, and are not long lasting enough for the respondents to become habituated. As I show in what follows, few if any of the growing list of papers on this topic accomplish that ideal.

A few asides before proceeding. First, those three obstacles are one reason this chapter is about local air pollution in particular and not about other environmental problems such as groundwater contamination or climate change. Air pollution varies from location to location on a daily or even hourly basis, leaving open lots of statistical options for identifying the causal effect of the pollution, across locations and across time periods, in short enough time so that people do not become habituated.

As a second aside, researchers use various terms of art in this context: happiness, subjective well-being, life satisfaction. Here I use "happiness" as a catch-all, though I recognize important differences. Partly my imprecision arises because many of the surveys ask imprecise questions. The General Social Survey in the US asks how "things are these days." That could be interpreted as a well-being question about this week, or a life satisfaction question about recent years. Some, like the World Values Survey (WVS), just ask how "happy" people are without specifying a time period. Others use language that conflates the two. The German SocioEconomic Panel (SOEP) asks "how satisfied are you with your life, at present?" And the European Social Survey (ESS) asks "how satisfied are you with your life as a whole nowadays?"

But another reason I use happiness to mean both temporary well-being and life satisfaction is because psychologists find that even if the survey questions don't conflate those ideas, survey respondents do. Schwarz and Clore (1983) provide a stark example. They telephoned people randomly on rainy and sunny days and asked them two questions: a question about their current state of mind, "how happy do you feel at this moment?" and an overall life satisfaction question, "how happy do you feel about your life as a whole?" Those called on sunny days reported higher well-being in response to both questions. That is a puzzle. If people make true assessments about their satisfaction with their entire lives, sunshine on the survey date should be immaterial.

A final reason to conflate life satisfaction and happiness is that pollution studies differ in whether they use daily fluctuations in pollution, which should affect momentary well-being but 
not life satisfaction, or local long-term pollution averages, which should affect life satisfaction and not momentary well-being, but might affect neither if people become habituated. Table 6.1 catalogs some of the happiness questions used in the studies surveyed in this chapter.

\section{[Table 6.1 about here.]}

In sum, life satisfaction might be the right question to ask in theory about long-term differences in pollution, but if people become habituated then the effect may only be discernable in short-term local variations, which shouldn't affect overall life satisfaction. So I use "happiness," blurring all of those distinctions.

In this chapter I address three questions. First, can the direct, causal effect of pollution on happiness be measured directly? Answering that question requires dealing with the three main problems identified: omitted variables, selection, and habituation. I survey recent work, and discuss the degree to which it surmounts those problems.

Second, how much does pollution decrease happiness? That's not easy to answer either, because many of the more than thirty recent published papers on this topic study different countries and time periods, use different measures of pollution and income, and ask different happiness questions. What does it mean that in one study, a one-day increase in the number of days particulate matter (PM10) exceeds 50 micrograms per cubic meter $\left(\mu \mathrm{g} / \mathrm{m}^{3}\right)$ reduces life satisfaction by 0.0005 on an 11-point scale (García-Mainar et al., 2015), while another study finds that a one $\mu \mathrm{g} / \mathrm{m}^{3}$ increase in sulfur dioxide $\left(\mathrm{SO}_{2}\right)$ decreases happiness by 0.07 units on a four-point scale (Menz and Welsch, 2012)? Which is larger?

To compare magnitudes across studies, I translate each into a willingness to pay for a one-standard-deviation improvement in air quality, for one day, in 2016 \$US. Every one of the papers includes income as a covariate, and the ratio of the pollution and income coefficients indicates the amount of extra money (typically annual income) an average respondent needs to compensate for a one-unit increase in pollution. Multiply that by the standard deviation in the pollutant, divide by 365 days per year, convert to US dollars and adjust for inflation to 2016, and we have an apples-to-apples comparison.

The third question I address is whether the measured willingness to pay derived from happiness studies comports with other negative effects of pollution. An enormous and growing body of research studies the effect of pollution on outcomes more tangible than happiness: health, mortality, productivity, test scores, etc. It turns out, perhaps surprisingly, that these disparate methods of valuing air quality match up well. The dollar value of willingness to pay for air quality derived from happiness studies looks remarkably similar to the dollar value typically assigned to decreased mortality or to the increased productivity from that air quality. 


\section{Literature review: The evidence as of $\mathbf{2 0 1 0}$}

A recent review (Frey et al., 2010) cited seven noteworthy studies estimating the effect of pollution on happiness, controlling for other covariates. Two used single surveys from one point in time - cross sections - comparing happiness of people in more and less polluted places (Welsch, 2002; MacKerron and Mourato, 2009). They estimate models like

$$
H_{i j}=f\left(P_{i j}, Y_{i j}, \boldsymbol{X}_{i j}, \varepsilon_{i j}\right)
$$

where $H_{i j}$ is some measure of happiness or stated well-being for person $i$ in location $j, P$ is some measure of pollution, $Y$ is income, $\boldsymbol{X}$ is a vector of other control variables, and $\varepsilon$ is an error term. Some estimate linear regression versions of (1); some estimate discrete choice models like ordered probits, acknowledging that happiness measures usually come in discrete categories; and some present robustness checks with multiple approaches. But most papers note that their qualitative findings do not depend on the choice of specification.

In the cross section estimates of (1), pollution differs across observations because the survey respondents live in different places. As Frey et al. note, comparing pollution and happiness in different places is "prone to omitted variable bias," the first of the three statistical obstacles highlighted above. In short, there are likely unobserved characteristics of locations correlated with both pollution and happiness. The error term $\varepsilon$ is correlated with $P$ and $H$, imparting a bias on the estimate of $\partial H / \partial P$.

To address omitted variable bias, four of the studies cited by Frey et al. use surveys collected at multiple times - repeated cross sections (Welsch, 2006; DiTella and MacCulloch, 2006; Levinson, 2012; Luechinger, 2010). Repeated cross sections help, making it feasible to control statistically for characteristics of places that are correlated with pollution and happiness but don't change over time. Consider proximity to the ocean. A single cross section has to compare the happiness of respondents in ocean-side unpolluted neighborhoods to inland polluted neighborhoods, conflating the effect of beach access on happiness with that of pollution on happiness. Repeated cross sections can compare respondents in either ocean-side or inland neighborhoods when the air quality changes and beach access has not. They estimate models like

$$
H_{i j t}=f\left(P_{j t}, Y_{i t}, \boldsymbol{X}_{i j t}, \boldsymbol{\delta}_{j}, \boldsymbol{\delta}_{t}, \varepsilon_{i j t}\right)
$$

where observations are individuals $i$ surveyed in location $j$ at time $t$. The vector $\boldsymbol{\delta}_{t}$ is a set of time dummy variables, and $\boldsymbol{\delta}_{j}$ is a set of location-specific dummy variables that capture unobserved fixed characteristics of locations, like proximity to the ocean. In (2) the estimate of $\partial H / \partial P$ is identified thanks to relative changes in pollution within locations over time. It asks: if a particular community becomes more polluted, do its inhabitants become less happy? By not comparing pollution and happiness across different communities, (2) avoids omitted variable bias due to unobserved community characteristics that are fixed over time and correlated with both happiness and pollution. 
But that still leaves open the two harder problems, selection and habituation. Two of the papers surveyed by Frey et al. tackle those. My paper (Levinson, 2012) uses repeated annual cross sections and daily variations in pollution. The idea is to compare similar individuals, in the same place during the same year, who happen to be surveyed on different days with more or less pollution. Respondents surveyed on polluted days are less happy. But respondents in polluted places, with relatively high annual average pollution, are not less happy. Short-term changes in pollution make people less happy, as expected. However, long-term differences do not, either because people become habituated or because people who care most about pollution choose the least polluted places.

The one other paper surveyed by Frey et al. that addresses selection and habituation is Luechinger (2009). His is also the only to use panel data, repeated observations of the same individuals at different times. Panel data enables estimation of

$$
H_{i j t}=f\left(P_{j t}, Y_{i t}, \boldsymbol{X}_{\boldsymbol{i j t}}, \boldsymbol{\delta}_{\boldsymbol{j}}, \boldsymbol{\delta}_{t}, \boldsymbol{\delta}_{i}, \varepsilon_{i j t}\right)
$$

where the novel addition is the vector $\boldsymbol{\delta}_{\boldsymbol{i}}$-individual-specific dummy variables. The estimate of $\partial H / \partial P$ in (3) is identified for a particular individual (who has presumably chosen to live in a clean or dirty place), when the air quality in that place changes over time. Luechinger measures annual sulfur dioxide $\left(\mathrm{SO}_{2}\right)$ levels at 533 monitoring stations in Germany for 19 years. To control for sorting by individuals into different locales, he compares responses by people who live downwind of large power plants that installed $\mathrm{SO}_{2}$ emissions control equipment, before and after the equipment was installed. And he compares the responses of downwind people whose air quality improved to similar people living upwind of the same power plants, before and after the equipment installation. Luechinger finds that the downwind people got happier after the installation, relative to their upwind neighbors who experienced less of an air quality improvement.

As of 2010, Luechinger's approach was state of the art. His paper addresses omitted variable bias by comparing pollution in the same places before and after changes in air quality. It solves the selection problem by comparing responses by the same individuals before and after the change. And it addresses habituation so long as we believe that it takes longer than a year or so to occur.

Since 2010 then there have been over 30 new published papers on this topic. They are summarized in Table 6.2. Below I describe how well these new papers overcome the three obstacles - omitted variables, selection, and habituation — and the answers they provide to the three questions: does pollution make people less happy? How much? And is the effect proportional to the estimates of pollution's effects on health and productivity?

[Table 6.2 about here.] 


\section{Does pollution make people less happy, and how much? Questions 1 and 2.}

One of the very first papers to examine the relationship between environmental quality and happiness (Welsch, 2002) recognized the importance of controlling for income, and in doing so, the possibility of examining the tradeoff between income and environmental quality as determinants of happiness. In short, the estimate of $\partial H / \partial P$ in equation (1) intends to capture the happiness reduction from a one-unit change in pollution; and the estimate $\partial H / \partial Y$ intends to capture the happiness increase from a one-unit change in income. Combined, the ratio

$$
\frac{\partial H / \partial P}{\partial H / \partial Y}=\left.\frac{-d Y}{d P}\right|_{d H \equiv 0}=M W T P
$$

then captures the amount of money necessary to compensate for a one-unit change in pollution. It is the marginal willingness to pay (MWTP) for a one-unit improvement in air quality. In a linear regression version of equation (1), that amounts simply to the ratio of the coefficient on pollution divided by the coefficient on income. Welsch calls this the "life satisfaction" approach to measuring willingness to pay for air quality. His 2002 paper estimates equation (4) in a simple way, using a cross section of 54 countries, national average reported well-being, national average pollution levels, and national per capita incomes. Though simple, the approach illustrated the methodology for subsequent research - the papers surveyed in Frey et al. 2010 and the 30-plus published since.

\section{Perceived pollution}

Among the 30 new papers, five use survey respondents' perceptions of local air quality rather than actual measured local pollution. Using self-reported perceived pollution has the convenience that all of the data are contained in one survey. But relying on perceived air pollution comes with obvious difficulties. Most critically, perceived pollution seems likely to be endogenous even if actual pollution is not. People most sensitive to poor air quality may both describe pollution as worse and be less happy. Some papers that estimate versions of equation (1) or (2) using perceived $P$ ignore the endogeneity issue, while others acknowledge the problem and demonstrate its significance empirically.

Beja (2012) finds that perceived poor local air quality reduces respondents' happiness in Latin America but is unable to show statistically significant results for other analyzed regions (Europe and US, Sub-Sahara Africa, Asia and Pacific). MacKerron and Mourato (2009) use their own survey of Londoners to show that both perceived and actual pollution is correlated with happiness. Of course, both could be endogenous for different reasons.

Only one paper (Goetzke and Rave, 2015) deals directly with the endogeneity of perceived $P$, controlling for both perceived and actual air pollution. They find that perceived air pollution is associated with lower happiness, but actual measured air pollution is associated with greater happiness. They instrument for perceived pollution using actual pollution, and the result 
is an insignificant but positive coefficient. Their explanation makes sense: both perceived and actual air pollution are endogenous for different reasons. Perceived pollution because people who care most about air pollution are least happy when they perceive it to be bad. And actual pollution, presumably, because of omitted variable bias and selection.

Beyond endogeneity concerns, using perceived air pollution from the same survey that asks about happiness raises concerns about standard survey biases: framing, question order, etc. By asking about air quality, the survey might make pollution more salient, or suggest to respondents that they should care about it or be less happy if it is bad, or happier if it is good. One of the advantages of the life satisfaction approach to valuing air quality is that measures of pollution taken from monitor readings independent of the happiness survey are unquestionably exogenous. For all of these reasons, most of the studies surveyed in Table 6.2 use actual air quality rather than perceived pollution.

\section{Cross sections}

Almost half of the new happiness-and-pollution studies published since the Frey et al. (2010) survey use cross section estimates of equation (1). They show that people who live in more-polluted places are less happy, usually but not always, and infer that pollution decreases happiness. That approach cannot account for any of the three obstacles: omitted variables, selection, or habituation. I list them in Table 6.2 for inclusiveness, but the time has probably come to stop publishing estimates from models that use only single cross sections.

\section{Repeated cross sections}

Table 6.2 lists 7 papers that estimate equation (2) using repeated cross sections, enabling the inclusion of location fixed effects $\left(\boldsymbol{\delta}_{j}\right)$ to control for unobserved location characteristics that may be correlated with happiness and pollution (e.g., beach access). Then $\partial H / \partial P$ can be identified by examining how happiness changes when pollution changes within a location.

Two of the repeated cross sections use country average measures of pollution and income (Menz and Welsch, 2010; Menz, 2011). That is, $P$ is measured as the country-wide average level of pollution, and $Y$ is some national average measure of per-capita income. That's not necessarily problematic, but it does aggregate away much of the variation. Both income and pollution vary less across countries than within countries. In the US, for example, the standard deviation of PM10 within locations across days is twice as large as it is across states or across years (Levinson, 2013).

Orru et al. (2016) examine 3770 observations from Estonia and two years of the ESS. They find local PM10 pollution to be negatively correlated with life satisfaction. But they do not seem to include local regional dummy variables ( $\boldsymbol{\delta}_{j}$ in equation (2)), so it is hard to tell whether or not the study capitalizes on the repeated cross sections to address omitted variable bias. And 
the income variables included are feelings about the households' incomes, rather than actual incomes, making tradeoffs difficult to interpret.

Menz and Welsch (2012) take an important step in the right direction, using five repeated cross sections across of more than 59,000 individuals in 10 countries. The income and other covariates are at the individual level. But the pollution measures are still country average concentrations of $\mathrm{SO}_{2}$ and $\mathrm{NO}_{2}$. The authors address this shortcoming, noting that "there is some variation of ambient $\mathrm{SO}_{2}$ concentrations" within France and within Italy, but that "all of Great Britain, Belgium, the Netherlands, Luxembourg, and Germany are more polluted than the other countries in our sample." And they argue that using country averages for $\mathrm{SO}_{2}$ and $\mathrm{NO}_{2}$ is less problematic than for PM10. Regardless of how much pollution varies within countries, their use of annual averages means that despite having 59,000 observations, they only have 50 different pollution readings - one for each of 10 countries in five different years.

Ferreira et al. (2013) take a bigger step closer to the ideal, examining more than 70,000 survey responses from the European Social Survey over 6 years. They regress happiness on annual average concentrations of $\mathrm{SO}_{2}$ and find a negative and significant relationship. An increase of one $\mu \mathrm{g} / \mathrm{m}^{3}$ is associated with a decline of from 0.016 to 0.030 points on an 11-point life satisfaction scale. Most of the regressions control for 23 country fixed effects but not the 248 regions used to characterize annual mean $\mathrm{SO}_{2}$ concentrations. So it is impossible to say how much of the 0.016 to 0.030 happiness effect is identified by cross-region differences and how much is attributable to changes in $\mathrm{SO}_{2}$ within regions over time. The cross-region differences will be affected by selection and habituation. The within-region differences perhaps less so. The largest negative relationship between $\mathrm{SO}_{2}$ and well being is estimated in the one regression with regional fixed effects.

Ferreira et al. don't translate their findings into MWTP, but their paper provides all the results necessary to do so. If we divide their pollution coefficient $(0.0302)$ by their log income coefficient (0.361) and multiply by the average income in the sample $(34,975)$, that yields the MWTP for a one-unit change in annual mean $\mathrm{SO}_{2}$ concentrations. Multiplying by the standard deviation in $\mathrm{SO}_{2}$ and dividing by 365 gives willingness to pay for a one-standard-deviation change in pollution, for one day. That number is reported in Table 6.2: 44.812016 \$US. It is among the highest such valuations.

García-Mainar et al. (2015) conduct a similar exercise, focusing on PM10 pollution in Spain. Their measure of pollution is the number of days per year that the average PM10 concentration in the respondent's region exceeds $50 \mu \mathrm{g} / \mathrm{m}^{3}$. They find an increase in the number of days PM10 exceeds that threshold reduces happiness by the same amount as a $€ 17$ decrease in annual income. Multiplying by the standard deviation of pollution, dividing by 365 , and converting to 2016 SUS yields a willingness to pay of $\$ 3.69$ to $\$ 4.35$ to avoid each day of high pollution. This estimate is among the lowest such valuations. 
Barrington-Leigh and Behzadnejad (2017) is the only new paper listed in Table 6.2 that uses pollution that varies on a short time frame, daily in their case. They use repeated cross sections of a non-public version of the Canadian Community Health Survey (CCHS) during 2005-2011, which identifies the interview date and postal code for each respondent. They then match each response to the pollution at nearby pollution monitors on the date of the interview. This approach is closest in spirit to my own paper (Levinson, 2012). Barrington-Leigh and Behzadnejad find MWTP of around \$US 2000 for an annual, one part-per-billion improvement in $\mathrm{SO}_{2}$, or about \$US 20 for a one-standard-deviation change for a day. That's nearly exactly the amount I found, though curiously they find the effect for $\mathrm{SO}_{2}$ and not other pollutants like particulates, while I found the effect for particulates and not for other pollutants like $\mathrm{SO}_{2}$. They explain the lack of effect for particulates as a result of the fact that levels are stable, mostly captured by geographic fixed effects. I explain the lack of effect for $\mathrm{SO}_{2}$ in my paper as the result of the fact that most areas in my study do not have significant $\mathrm{SO}_{2}$ pollution. $\mathrm{SO}_{2}$ being less ubiquitous, it poses a problem mostly downwind of coal-fired power plants. Neither explanation seems implausible on its own, but combined they start to sound like ex post rationalizations of potentially spurious results.

\section{Panels}

Ideally, to solve the three problems of omitted variables, selection, and habituation, we'd have panel data on the same individuals surveyed at different times and experiencing different air pollution. Three recent papers use panel data. Giovanis and Ozdamar (2016) use the Swiss Household Panel Survey (SHPS) from 2000 to 2013 to estimate a version of equation (3) that includes individual respondent fixed effects $\left(\boldsymbol{\delta}_{i}\right)$. They include local daily air pollution at the location of the survey on the date of the survey. They find large and statistically significant MWTP for $\mathrm{O}_{3}, \mathrm{SO}_{2}$, and $\mathrm{NO}_{2}$, and smaller and less significant MWTP for CO and PM10. The results, summarized in Table 6.2, are not dissimilar from prior work using less sophisticated data.

Those same two authors, Ozdamar and Giovanis (2017), conduct a similar exercise for the UK. They use the British Household Panel Survey (BHPS) for 18 years, from 1991 to 2009. Instead of a standard happiness or life satisfaction question, BHPS asks 12 questions about "mental well-being." Ozdamar and Giovanis combine those 12 answers into one scalar. They focus on non-movers because those are less likely to have made choices based on the local conditions such as pollution. The main results use only households eligible for public assistance, so the findings cannot necessarily be interpreted generally. All three of the pollutants studied $\left(\mathrm{O}_{3}, \mathrm{NO}_{\mathrm{x}}\right.$, and $\left.\mathrm{CO}\right)$ are associated with more reported mental stress, though not statistically significantly so for $\mathrm{CO}$. That makes sense given that ambient $\mathrm{CO}$ passes mostly unnoticed. Income is negatively associated with mental stress. And the tradeoff between income and pollution is smaller than in their Swiss study: the numbers for $\mathrm{O}_{3}$ and $\mathrm{NO}_{\mathrm{x}}$ are about one-third as large. 
Zhang et al. (2017a) conduct a third such exercise, this time for China. They use three waves of the China Family Panel Studies (CFPS) from 2010, 2012, and 2014. The authors track individuals over time, and know the place and date of each interview so it can be matched to local pollution data. All three waves of the CFPS ask the life satisfaction question "Overall, how satisfied are you with your life?" Respondents were also asked questions closer to momentary hedonic happiness: one about current depressive symptoms, and another about whether they were "hard to cheer up in the past month." Controlling for other things, including individual respondent fixed effects, Zhang et al. find current local air pollution to be uncorrelated with the life satisfaction question, but significantly correlated with the two measures of current happiness.

Notably, despite all its strengths, Zhang et al. generate a result that is remarkably consistent with papers that lack those advantages. A one-standard-deviation improvement in air quality raises the average person's happiness by an amount equivalent to income of \$US 4 per day. That similarity deserves caution however. Most of the other studies in Table 6.2 focus on developed countries, Europe or the US. It stands to reason that MWTP might be different in China, where pollution levels are higher and incomes are lower. But more importantly, most of the other studies use a life satisfaction question, ignoring the fact that daily variations in pollution should not affect overall life satisfaction. Zhang et al. find no effect of pollution on life satisfaction, which contrasts prior published studies but is to be expected, and do find an effect on hedonic happiness, which they use to generate their \$US 4 MWTP.

\section{Comparisons to effects of pollution on health and productivity. Question 3.}

As noted at the top of this chapter, pollution makes people sick and less productive. For researchers who might be skeptical of "happiness" survey questions or willingness to pay estimates derived from the life satisfaction approach, a natural question to ask is how the happiness results in Table 6.2 compare with the results of the health and productivity research.

Luechinger (2014) provides an excellent such comparison. He uses the exact same empirical strategy as in his 2009 happiness paper: examining respondents upwind and downwind of power plants before and after they install technology to reduce $\mathrm{SO}_{2}$ emissions. Except instead of happiness, his 2014 paper examines infant mortality. He finds that a one $\mu \mathrm{g} / \mathrm{m}^{3}$ increase in $\mathrm{SO}_{2}$ results in 0.026 to 0.045 extra infant deaths per 1000 live births. His 2009 paper finds a willingness-to-pay for clean air of $€ 183$ to $€ 313$, or $\$ 230$ to $\$ 349$ in 2016 \$US. Putting these two estimates together yields a value of statistical life (VSL) of $\$ 5.1$ to $\$ 15.2$ million. This estimate is remarkably consistent with VSL estimates used in policy analysis. For example, the US Environmental Protection Agency (EPA) uses a central VSL estimate of \$US 8.8 million.

To my knowledge there are no other papers like the pair by Luechinger, estimating effects of pollution on happiness and some less subjective measure of welfare. But there are lots of health and productivity papers that could be compared to the happiness papers in Table 6.2. Here's an example. Heutel and Ruhm (2016) estimate that a one-standard-deviation increase in 
$\mathrm{CO}$ increases mortality rates by 1.6 percent. Underlying mortality rates average 8.2 per thousand, so that's 0.13 additional deaths per thousand per year. Giovanis and Ozdamar (2016) calculate a happiness-based willingness to pay for a one-standard-deviation reduction in CO of \$US 5.48. Putting those two together yields a VSL of \$US 15.6 million.

Other examples come from work comparing pollution and productivity. Graff Zivin and Neidell (2012) show that a $10 \mathrm{ppb}$ decrease in ozone concentrations increases agricultural worker productivity in California by 5.5 percent. That's approximately a one-standard-deviation change. If workers earn the minimum wage of $\$$ US 10.10 per hour, or $\$ 80.80$ per eight-hour day, a 5.5 percent change is worth about $\$ 4.50$, not out of line with the estimates on the rightmost column of Table 6.2.

Here's another productivity example. He et al. (2017) show that a $10 \mu \mathrm{g} / \mathrm{m}^{3}$ increase in PM2.5 reduces factory worker productivity in China by one percent. ${ }^{2}$ The standard deviation of PM2.5 in their sample is 35.3, and the average output per worker per shift is \$US 20. So a onestandard-deviation change in PM2.5 costs about \$0.75. That's considerably smaller than the \$US 6.55 Giovanis and Ozdamar estimated for PM10 in Switzerland. But Chinese income per capita is less than one-fourth that of Switzerland.

Many papers similar in spirit to these four examples estimate the effect of pollution on health, mortality, and productivity. Graff Zivin and Neidell (2013) and Curry et al. (2014) provide comprehensive reviews. The sampling here suggests that the papers estimating the effect of pollution on happiness generate comparable results.

\section{Discussion}

\section{Few studies address omitted variables, selection, or habituation}

I raised three concerns at the start of this review. Many of the published papers to date do mention concerns about omitted variables, though few address the issue directly. Most papers ignore selection, and almost none mention habituation. Most papers rely on cross sections of data, comparing annual average national pollution in different countries. Only two papers measure happiness as a function of daily fluctuations in air quality, on the date and in the place the survey question was asked. Only four use panels, following the same individual as pollution changes in the same place over time. And only one of the panel studies uses daily fluctuations, Zhang et al. (2017a) for China. That seems like the current state of the art methodology, and a strategy worth replicating. How do the same individuals respond to changing daily air pollution?

For the cross section studies listed in Table 6.2, which ignore all three concerns, it may not be surprising that the results vary widely, from negative (pollution makes people happier) to a willingness-to-pay of \$US 170 per day for a one-standard-deviation reduction in pollution. But

\footnotetext{
${ }^{2}$ PM10 refers to particulate matter smaller than 10 microns, and PM2.5 to particulate matter smaller than 2.5 microns.
} 
the range of magnitudes is much smaller and more sensible among repeated cross sections, which at least address omitted fixed location characteristics. Those estimates range from a few dollars to \$US 44. That's not a wide range given the variety of pollutants, countries, and happiness questions involved. As for the few studies using panels or daily fluctuations, it's too early to say whether there's a consensus. The estimates of willingness to pay range from about \$US 4 (for an index of air pollution in China) to \$US 34 ( $\mathrm{SO}_{2}$ in Switzerland), a range similar to that for repeated cross sections that do not account for selection or habituation as well.

To be clear, just because the estimates from papers that account for selection and habituation fall in the same general range does not excuse ignoring those issues. And just because the few studies that do use panel data or daily fluctuations have estimates within a relatively narrow bound doesn't mean they are correct. There remain large concerns that almost none of the papers in Table 6.2 address. One of those is that income itself may be endogenous.

\section{Endogenous income}

Using happiness to value air quality requires estimating both the numerator and the denominator of equation (4). For the denominator, $\partial H / \partial Y$, we need to know the effect of income on happiness, but income may be endogenous. Inherently happier people may earn higher incomes. Luttmer (2005) estimates the effect of income on happiness where he instruments for household income using interactions between the respondents' and spouses' industry, occupation, and location. He finds income coefficients in instrumental variables specifications that are larger than in OLS specifications, suggesting that equation (4) overstates the MWTP for clean air. ${ }^{3}$

Almost none of the papers in Table 6.2 even remark upon this concern, let alone try to address it. Luechinger (2009) and Levinson (2012) instrument for income using instruments like Luttmer's, lowering the MWTP. But since then most papers have ignored the issue.

\section{Selection, migration, and contagious unhappiness}

Another possible concern with these analyses is that the type of people who choose to live in polluted areas, or even areas likely to have occasional polluted days, may be different from people in reliably clean areas. Only a few of the papers in Table 6.2 address this. In their two papers, Giovanis and Ozdamar distinguish between people who have moved recently and those who have not, on the grounds that pollution may have played a role in movers' choice of where to move. And the studies that use daily fluctuations, like Zhang et al. (2017a) and Barrington-Leigh and Behzadnejad (2017) control for selection by identifying the effect of pollution on happiness in a time frame that is shorter than those during which people typically

\footnotetext{
${ }^{3}$ But see Pischke and Schwant (2012) for a note of caution about Luttmer's approach to instrumenting for income.
} 
would have time to move. But even those studies ignore the fact that areas known to have occasional highly polluted days may attract residents who are less sensitive to pollution.

More subtly, once we open the door to selection of location by residents, maybe we should be concerned about why, in equilibrium, there are any differences in happiness across jurisdictions. After controlling for everything on the right-hand-side, shouldn't happiness be equal everywhere? If not, people should move to the happier places. But Glaeser et al. (2016) show that people continue to move to cities in the US with lower than average levels of stated well-being, or happiness, and that individuals who migrate to cities with lower happiness become less happy themselves.

Glaeser et al.'s results have multiple possible interpretations for this happiness-pollution line of research. The fact that people migrate to low-happiness places could mean that people less concerned about the particular features of those target cities that make their residents unhappy are more likely to move there. Pollution-sensitive people don't move to polluted cities. That's concerning because it means that regressions of happiness on pollution will understate how much pollution reduces happiness for a typical person.

Another interpretation is that happiness itself may be contagious. Glaeser et al. show that people who move to unhappy cities become less happy themselves. If the decline in happiness is the result of the underlying characteristics of those cities, like pollution, then it would seem to be related to the causal effect of pollution on happiness, even though the migrants have selected the cities. But if the decline in happiness results from being surrounded by other unhappy people, then that spurious correlation plagues all of the pollution-happiness results in Table 6.2. If pollution makes you and everyone around you unhappy, then you are unhappy for two reasonsthe direct effect of the pollution, and the indirect effect of pollution through everybody else. That poses a daunting empirical challenge, because your and everybody else's happiness will be correlated with all the same observable and unobservable local conditions.

\section{Habituation, short-termism bias, and using happiness to value air quality}

People get habituated, which means that long-lasting circumstances have curiously small effects on life satisfaction. But a similar problem happens in reverse. Earlier I described how people report greater overall life satisfaction if they happen to be surveyed on a sunny day. Schwarz and Strack (1991) describe an even more trivial effect. They randomly placed ten cents where some survey respondents could find it, and then interviewed those people about their life satisfaction. Those that found the coin were significantly more satisfied with their lives. A life satisfaction methodology would suggest that people are willing to give up a significant amount of annual income in exchange for finding ten cents. Call it "short-termism." So habituation means that long-lasting circumstances affect life satisfaction too little, and short-termism means even inconsequential temporary circumstances affect life satisfaction too much. That seems 
problematic for using reported well-being to value air quality-either long-lasting differences in pollution or temporary daily fluctuations.

In brief, the happiness approach to evaluating policy has shortcomings. Using daily fluctuations is problematic if public policy is aimed at long-term changes in air quality. But if people become habituated to long-term average levels, the happiness approach may be useless except as identified by short-term fluctuations.

Can we use happiness to value air quality anyway? An optimistic, or maybe even Pollyannaish, view would be that we are fortunate that people exhibit both behaviors. Habituation without short-termism would mean there would be no way of using happiness to value air quality. People would be habituated to long-term changes and would not mistake shortterm changes for permanence. There would be no effect on life satisfaction of either local annual average air pollution levels across regions, thanks to habituation, or to daily fluctuations within regions, thanks to the lack of short-termism bias. Fortunately, responses to life satisfaction questions do vary with temporary circumstances, like today's sunshine or pollution. Shorttermism may partly save this methodology from habituation. On the other hand, there's no guarantee that the valuations of public goods with habituation and short-termism would be the same as the valuations with neither, or that the magnitudes would be comparable.

The pessimistic view was stated by Schwarz and Strack (1999) even before the recent growth of policy applications began: "What is being assessed, and how, seems too context dependent to provide reliable information about a population's well-being, let alone information that can guide public policy." If that seems too negative, recall that other methods of valuing environmental quality - hedonic property values regressions, travel cost models, contingent valuation - have their own biases and unaddressed issues. The past 15 years have seen the introduction of happiness economics as a new methodology for valuing air quality, a tool with its own new set of hurdles and biases that must be confronted.

\section{Conclusions}

I promised answers to three questions: Does pollution make people unhappy? How much? And is the effect proportional to estimates of pollution's effects on health and productivity? The answer to the first is unequivocal: "yes." There are now dozens of studies measuring negative correlations between happiness and pollution, in a variety of countries, using different well-being questions, pollution measures, and empirical strategies.

The second, "how much?", is tougher to answer. Because all the studies use different units, the coefficients on pollution cannot be compared directly. One way of comparing the pollution coefficients across different studies is to examine how they each relate to the income coefficient within the same studies, as in equation (4). Even if we don't consider this a valid approach to valuing air quality, it is a means of comparing results across studies that use different units of pollution and well-being. Here there's a division. Papers using only single cross 
sections have results that vary from negative (pollution increases happiness) to people being willing to pay hundreds of dollars for a single day of cleaner air. Neither is credible. But if we focus only on the studies that use repeated cross section, or better yet use panels of data or daily fluctuations in air quality, the results fall into a reasonable range, from 4 to 40 \$US for a day of cleaner air.

Third, how do these results compare to estimates of pollution's effect on more tangible outcomes, like health and productivity? If we take the MWTP estimate from the happiness papers, and apply them to recent studies of the effect of pollution on mortality, we get an estimate of the VSL. Those VSL numbers are similar to ones used by policymakers and that come directly from hedonic wage regressions or contingent valuation questions. I the same way, if we take the MWTP from happiness papers and apply them to recent studies of the effect of pollution on productivity, we find that the monetary value of people's lost happiness from pollution is comparable to their lost productivity.

Taken all together, the answers provide the grounds for cautious optimism about this line of inquiry. Caution because most of the studies to date suffer from problems associated with omitted variables, selection, and habituation, as well as endogenous income and contagious happiness. But optimism because a small handful of studies now use panel data and short-term fluctuations in pollution to address some of these problems. And those newer studies provide estimates of willingness to pay for air quality that are consistent with outcomes economists have more experience and comfort measuring, like health and productivity.

\section{References}

Ambrey, Christopher, Christopher Fleming, and Andrew Yiu-Chung Chan (2014), 'Estimating the cost of air pollution in South East Queensland: An application of the life satisfaction non-market valuation approach' Ecological Economics, 97, 172-181.

Barrington-Leigh, C., and F. Behzadnejad (2017), 'Evaluating the short-term cost of low-level local air pollution: a life satisfaction approach', Environmental Economics and Policy Studies, 19 (2), 269-298.

Beja, E. L. (2012), 'Subjective well-being approach to environmental valuation: evidence for greenhouse gas emissions', Social Indicators Research, 109 (2), 243-266.

Cunado, Juncal and Fernando Perez de Gracia (2013), 'Environment and Happiness: New Evidence for Spain’ Social Indicators Research, 112(3), 549-567.

Currie, Janet, Joshua Graff Zivin, Jamie Mullins, and Matthew Neidell (2014), 'What Do We Know About Short- and Long-Term Effects of Early-Life Exposure to Pollution?' Annual Review of Resource Economics, 6:217-47. 
Di Tella R, and MacCulloch RJ (2007), 'Gross national happiness as an answer to the Easterlin paradox?', Journal of Development Economics, 86:22-42.

Dolan, P., and K. Laffan (2016), 'Bad air days: The effects of air quality on different measures of subjective well-being', Journal of Benefit-Cost Analysis, 7 (1), 147-195.

Ebenstein, Avraham, Victor Lavy, and Sefi Roth (2016), 'The Long-Run Economic Consequences of High-Stakes Examinations: Evidence from Transitory Variation in Pollution', American Economic Journal: Applied Economics, 8 (4), 36-65.

Ferreira, S., A. Akay, F. Brereton, J. Cuñado, P. Martinsson, M. Moro, and T.F. Ningal (2013), 'Life satisfaction and air quality in Europe', Ecological Economics, 88, 1-10.

Ferreira, S., and M. Moro (2010), 'On the use of subjective well-being data for environmental valuation’, Environmental and Resource Economics, 46 (3), 249-273.

Ferreira, S., and M. Moro (2013), 'Income and preferences for the environment: evidence from subjective well-being data', Environment and Planning A, 45 (3), 650-667.

Frey, Bruno, Simon Luechinger, and Alois Stutzer (2010), 'Life Satisfaction Approach to Environmental Valuation', Annual Review of Resource Economics, 2:139-160.

García-Mainar, I., V.M. Montuenga, and M. Navarro-Paniagua (2015), 'Workplace environmental conditions and life satisfaction in Spain', Ecological Economics, 119, 136146.

Giovanis, E., and O. Ozdamar (2016), 'Structural Equation Modelling and the Causal Effect of Permanent Income on Life Satisfaction: The Case of Air Pollution Valuation in Switzerland', Journal of Economic Surveys, 30 (3), 430-459.

Glaeser, E. L., J.D. Gottlieb, and O. Ziv (2016), 'Unhappy cities', Journal of labor economics, 34 (S2), S129-S182.

Goetzke, F., and T. Rave (2015), 'Regional Air Quality and Happiness in Germany', International Regional Science Review, 38 (4), 437-451.

Graff Zivin, Joshua, and Matthew Neidell (2012), 'The Impact of Pollution on Worker Productivity', American Economic Review, 102(7): 3652-73.

Graff Zivin, Joshua and Matthew Neidell (2013), 'Environment, Health, and Human Capital,' Journal of Economic Literature, 51(3):689-730.

Graham, Carol (2009), 'Why Societies Stay Stuck in Bad Equilibrium: Insights from Happiness Studies amidst Prosperity and Adversity', Paper presented to the IZA Conference on 
Frontiers in Labor Economics: The Economics of Well-Being and Happiness, Washington, DC.

He, Jiaxiu, Haoming Liu and Alberto Salvo (2019), `Severe Air Pollution and Labor Productivity: Evidence from Industrial Towns in China', American Economic Journal: Applied Economics 11(1):173-201.

Heutel, Garth and Christopher Ruhm (2016), 'Air Pollution and Procyclical Mortality', Journal of the Association of Environmental and Resource Economists, 3(3):667-706.

Jidong, Y., and Z. Yiran (2015), 'Happiness and Air Pollution', China Economist, 10 (5), 62-77.

León, C. J., and J. E. Araña (2015), 'A Bayesian Model Averaging Approach to the Transfer of Subjective Well-Being Values of Air Quality', in Johnston R., Rolfe J., Rosenberger R., and Brouwer R. (eds.), Benefit Transfer of Environmental and Resource Values, The Economics of Non-Market Goods and Resources, vol 14. Netherlands: Springer, pp. 489505.

Levinson, A. (2012), 'Valuing public goods using happiness data: The case of air quality', Journal of Public Economics, 96 (9-10), 869-880.

Levinson, A. (2013), 'Happiness, Behavioral Economics, and Public Policy', NBER working paper 19329.

Liao, P. S., D. Shaw, and Y. M. Lin (2015), 'Environmental quality and life satisfaction: Subjective versus objective measures of air quality', Social Indicators Research, 124 (2), 599-616.

Luechinger, S. (2009), 'Valuing air quality using the life satisfaction approach', The Economic Journal, 119 (536), 482-515.

Luechinger, S. (2010), 'Life satisfaction and transboundary air pollution', Economics Letters, 107 (1), 4-6.

Luechinger, S. (2014), 'Air pollution and infant mortality: A natural experiment from power plant desulfurization', Journal of Health Economics, 37:219-231.

Luttmer, Erzo F.P. (2005), 'Neighbors as Negatives: Relative Earnings and Well-being', Quarterly Journal of Economics, 120(3): 963-1002.

MacKerron G, and S. Mourato (2009), 'Life satisfaction and air quality in London', Ecological Economics, 68:1441-1453.

Menz, T. (2011), 'Do people habituate to air pollution? Evidence from international life satisfaction data', Ecological Economics, 71, 211-219. 
Menz, T., and H. Welsch (2010), 'Population aging and environmental preferences in OECD countries: The case of air pollution', Ecological Economics, 69 (12), 2582-2589.

Menz, T., and H. Welsch (2012), 'Life-cycle and cohort effects in the valuation of air quality: evidence from subjective well-being data', Land Economics, 88 (2), 300-325.

Neidell, Matthew (2017), ‘Air pollution and worker productivity', IZA World of Labor 2017: 363 doi: 10.15185/izawol.363.

OECD (2016), 'The Economic Consequences of Outdoor Air Pollution', OECD publishing, Paris.

Orru, K., H. Orru, M. Maasikmets, R. Hendrikson, and M. Ainsaar (2016), 'Well-being and environmental quality: Does pollution affect life satisfaction?', Quality of Life Research, 25 (3), 699-705.

Ozdamar, O. (2016), 'Exposure to air pollution and crime in the neighbourhood: Evidence from life satisfaction data in Turkey', International Journal of Social Economics, 43 (12), 1233-1253.

Ozdamar, O., and E. Giovanis (2017), 'The Causal Effects of Income Support and Housing Benefits on Mental Well-Being: An Application of a Bayesian Network', Metroeconomica, 68 (3), 398-424.

Pischke, Jorn-Steffen and Hannes Schwandt (212), 'A Cautionary Note on Using Industry Affiliation to Predict Income', NBER working paper 18384.

Rehdanz, K., and D. Maddison (2008), 'Local environmental quality and life-satisfaction in Germany', Ecological Economics, 64 (4), 787-797.

Schwarz, Norbert, and Fritz Strack (1991), 'Evaluating One's Life: a Judgment Model of Subjective Well-Being' in Subjective Well-Being: An Interdisciplinary Perspective, ed. Fritz Strack, Michael Argyle, and Norbert Schwarz, 27-47. Oxford, UK: Pergamon Press.

Schwarz Norbert, and Fritz Strack (1999), 'Reports of Subjective Well Being: Judgmental Processes and Their Methodological Implications" in Well Being: The Foundation of Hedonic Psychology, ed. D. Kahneman, E. Diener, N. Schwarz. Russell Sage Foundation, New York.

Schwarz, Norbert and Gerald Clore (1983), 'Mood, Misattribution, and Judgments of WellBeing: Informative and Directive Functions of Affective States' Journal of Personality and Social Psychology 102: 513-523. 
Smyth, R., V. Mishra, and X. Qian (2008), 'The environment and well-being in urban China', Ecological Economics, 68 (1), 547-555.

Tsurumi, T., and S. Managi (2017), 'Monetary valuations of life conditions in a consistent framework: The life satisfaction approach', Journal of Happiness Studies 18(5): 12751303.

Tsurumi, T., H. Mizobuchi, and S. Managi (2015), 'A monetary evaluation of life', in Shunsuke Managi (ed.), The Economics of Green Growth: New Indicators for Sustainable Societies, England, USA, and Canada: Routledge, pp. 157-195.

Welsch, H. (2002), 'Preferences over prosperity and pollution: environmental valuation based on happiness surveys', Kyklos, 55 (4), 473-494.

Welsch H. (2006), 'Environment and happiness: valuation of air pollution using life satisfaction data', Ecological Economics, 58(4), 801-813

Welsch, H. (2007), 'Environmental welfare analysis: A life satisfaction approach', Ecological Economics, 62 (3), 544-551.

Xu, J., J. Li (2016), 'Tax Payment, Social Contribution for Pollution Prevention and Happiness', Problemy Ekorozwoju - Problems of Sustainable Development, 11 (1), 59-64.

Zhang, X., X. Zhang, and X. Chen (2017a), 'Happiness in the air: How does a dirty sky affect mental health and subjective well-being?', Journal of Environmental Economics and Management, 85, 81-94.

Zhang, X., X. Zhang, X., and X. Chen (2017b), 'Valuing Air Quality Using Happiness Data: The Case of China', Ecological Economics, 137, 29-36. 


\section{Table 6.1: Happiness Survey Questions}

\begin{tabular}{|c|c|c|}
\hline Data source & Acronym & Question \\
\hline European Social Survey & ESS & $\begin{array}{l}\text { All things considered, how satisfied are you with your life } \\
\text { as a whole nowadays? From } 0 \text { (extremely dissatisfied) to } \\
10 \text { (extremely satisfied). }\end{array}$ \\
\hline World Values Survey & WVS & $\begin{array}{l}\text { Would you say you are happy or not? From Very happy (1) } \\
\text { to not at all happy (4). }\end{array}$ \\
\hline $\begin{array}{l}\text { German Socio-Economic } \\
\text { Panel }\end{array}$ & SOEP & $\begin{array}{l}\text { How satisfied are you with your life, at present, all things } \\
\text { considered? ( } 10 \text { point scale) }\end{array}$ \\
\hline Eurobarometer & & $\begin{array}{l}\text { On the whole, are you very satisfied, } \\
\text { fairly satisfied, not very satisfied, or not at all } \\
\text { satisfied with the life you lead? }\end{array}$ \\
\hline $\begin{array}{l}\text { Spanish Quality of Working } \\
\text { Life Survey (Encuesta de } \\
\text { Calidad de Vida en el } \\
\text { Trabajo) }\end{array}$ & ECVT & $\begin{array}{l}\text { Please, rate between } 0 \text { (not satisfied at all), and } 10 \text { (very } \\
\text { satisfied), your degree of satisfaction with your personal } \\
\text { life. }\end{array}$ \\
\hline $\begin{array}{l}\text { Chinese General Social } \\
\text { Survey }\end{array}$ & CGSS & $\begin{array}{l}\text { Are you happy with your life? From } 1 \text { (very unhappy) to } 5 \\
\text { (completely happy). }\end{array}$ \\
\hline Taiwan Social Change Survey & TSCS & Life Satisfaction, 5-point scale. \\
\hline UK Annual Population Survey & UK APS & $\begin{array}{l}\text { Satisfaction: "Overall, how satisfied are you with your life } \\
\text { nowadays?" 11-point scale } \\
\text { Happiness: "Overall, how happy did you feel yesterday?" }\end{array}$ \\
\hline $\begin{array}{l}\text { Swiss Household Panel } \\
\text { Survey }\end{array}$ & SHPS & $\begin{array}{l}\text { In general, how satisfied are you with your life } \\
\text { if } 0 \text { means "not at all satisfied" and } 10 \text { means } \\
\text { "completely satisfied"? }\end{array}$ \\
\hline $\begin{array}{l}\text { Behavioral Risk Factor } \\
\text { Surveillance System }\end{array}$ & BRFSS & $\begin{array}{l}\text { In general, how satisfied are you with your life? From (1) } \\
\text { "very satisfied" to (4) "very dissatisfied." }\end{array}$ \\
\hline China Family Panel Studies & CFPS & $\begin{array}{l}\text { Overall, how satisfied are you with your life?" on a } \\
\text { scale from } 1 \text { (not satisfied at all) to } 5 \text { (very satisfied). }\end{array}$ \\
\hline $\begin{array}{l}\text { Canadian Community Health } \\
\text { Survey }\end{array}$ & $\mathrm{CCHS}$ & $\begin{array}{l}\text { How satisfied are you with your life in general? } 5 \text { or } 11 \\
\text { levels, depending on year. }\end{array}$ \\
\hline
\end{tabular}


Table 6.2: New Published Papers on Pollution and Happiness

\begin{tabular}{|c|c|c|c|c|c|}
\hline Study & Pollutant & Data & $\begin{array}{l}\text { Number of } \\
\text { observations }\end{array}$ & Main result & $\begin{array}{l}\text { Willingness to pay for a } 1 \\
\text { std deviation improvement } \\
\text { (2016 \$US per day) }{ }^{*}\end{array}$ \\
\hline & $(1)$ & $(2)$ & (3) & (4) & $(5)$ \\
\hline \multicolumn{6}{|c|}{ Perceived Air Pollution } \\
\hline $\begin{array}{l}\text { Rehdanz and } \\
\text { Maddison (2008) }\end{array}$ & $\begin{array}{l}\text { Perceived air } \\
\text { pollution }\end{array}$ & $\begin{array}{l}\text { SOEP in } 1994,1999, \\
\text { and } 2004 .\end{array}$ & 23,014 & & \\
\hline Beja (2012) & $\begin{array}{l}\text { Perceived air } \\
\text { pollution }\end{array}$ & 2005 WVS & 43,408 & $\begin{array}{l}\text { Pollution and happiness } \\
\text { negatively correlated in } \\
\text { Latin America, not } \\
\text { elsewhere. }\end{array}$ & \\
\hline $\begin{array}{l}\text { Goetzke and Rave } \\
\text { (2015) }\end{array}$ & $\begin{array}{l}\text { Perceived air } \\
\text { pollution and } \\
\text { air pollution factor } \\
\text { (comprised of } \mathrm{SO}_{2} \text {, } \\
\mathrm{NO}_{x}, \mathrm{PM} 10 \text { ) }\end{array}$ & $\begin{array}{l}\text { SOEP, perceived and } \\
\text { actual pollution }\end{array}$ & 7,802 & $\begin{array}{l}\text { Perceived pollution } \\
\text { endogenous }\end{array}$ & \\
\hline Ozdamar (2016) & $\begin{array}{l}\text { Self-reported } \\
\text { exposure to air } \\
\text { pollution }\end{array}$ & $\begin{array}{l}\text { Turkish health } \\
\text { survey 2010, } 2012\end{array}$ & 14,400 & & \\
\hline Xu and Li (2016) & $\begin{array}{l}\text { "seriousness" of } \\
\text { pollution, 4-point } \\
\text { scale }\end{array}$ & 2007 WVS for China & 1,991 & $\begin{array}{l}\text { Perceived seriousness of } \\
\text { pollution negatively } \\
\text { associated with happiness. }\end{array}$ & \\
\hline $\begin{array}{l}\text { MacKerron and } \\
\text { Mourato (2009) }\end{array}$ & $\mathrm{NO}_{\mathrm{x}}$ & $\begin{array}{l}\text { Original survey of } \\
\text { London. }\end{array}$ & 400 & $\begin{array}{l}\text { Both perceived and actual } \\
\text { air quality affect happiness }\end{array}$ & \\
\hline \multicolumn{6}{|l|}{ Cross Sections } \\
\hline Welsch (2007) & $\mathrm{NO}_{2}$ & $\begin{array}{l}\text { Cross section of } \\
\text { average national } \\
\text { happiness and } \\
\text { income in } 1995 .\end{array}$ & 54 & & \\
\hline Smyth et al. (2008) & $\begin{array}{l}\mathrm{SO}_{2} \text { emissions per } \\
\text { capita }\end{array}$ & $\begin{array}{l}\text { Chinese cross } \\
\text { section, } 30 \text { cities in } \\
2003 .\end{array}$ & 8,890 & & \\
\hline $\begin{array}{l}\text { Ferreira and Moro } \\
(2010)\end{array}$ & $\begin{array}{l}\text { PM10 (annual local } \\
\text { mean) }\end{array}$ & $\begin{array}{l}\text { Cross section of Irish } \\
\text { locations }\end{array}$ & 1,184 & $€ 945$ per $\mu \mathrm{g} / \mathrm{m}^{3}$ & $\$ 9.56$ \\
\hline
\end{tabular}




\begin{tabular}{|c|c|c|c|c|c|}
\hline $\begin{array}{l}\text { Ferreira and Moro } \\
\text { (2013) }\end{array}$ & $\begin{array}{l}\text { PM10 (annual local } \\
\text { mean) }\end{array}$ & $\begin{array}{l}\text { Cross section of Irish } \\
\text { locations }\end{array}$ & 1,063 & $€ 2,496$ per $\mu \mathrm{g} / \mathrm{m}^{3}$ & $\$ 31.57$ \\
\hline $\begin{array}{l}\text { Cuñado and De } \\
\text { Gracia (2013) }\end{array}$ & $\mathrm{CO}_{2}, \mathrm{NO}_{2}, \mathrm{PM} 10$ & $\begin{array}{l}\text { European Social } \\
\text { Survey } 2008 \text { for } 17 \\
\text { regions of Spain. }\end{array}$ & 2,565 & $\begin{array}{l}€ 325-609 \text { for one day } \\
\text { reduction in days }>50 \\
\mu \mathrm{g} / \mathrm{m}^{3}\end{array}$ & no std dev reported \\
\hline Ambrey et al. (2014) & $\begin{array}{l}\text { PM10 (local days per } \\
\text { year exceeding } \\
\text { guidelines) }\end{array}$ & $\begin{array}{l}\text { HILDA Survey } \\
\text { Australia } 2001\end{array}$ & 919 & $\begin{array}{l}\text { AUD } 5164 \text { for one day } \\
\text { reduction }\end{array}$ & $\$ 30.12$ \\
\hline $\begin{array}{l}\text { León and Araña } \\
\text { (2015) }\end{array}$ & $\begin{array}{l}\mathrm{NO}_{2}, \mathrm{SO}_{2} \text { (projected } \\
\text { local levels at time } \\
\text { of survey) }\end{array}$ & $\begin{array}{l}\text { UK, Norway, } \\
\text { Sweden, } 2010\end{array}$ & 3,830 & $\begin{array}{l}\mathrm{NO}_{2}: € 402 \text { in UK } \\
€ 918 \text { in Norway } \\
\mathrm{SO}_{2}: € 763 \text { in UK } \\
€ 1439 \text { in Sweden }\end{array}$ & $\begin{array}{l}\mathrm{NO}_{2}: \$ 1.61 \text { (UK) } \\
\$ 3.38 \text { (Norway) } \\
\mathrm{SO}_{2}: \$ 3.05 \text { (UK) } \\
\$ 5.76 \text { (Sweden) }\end{array}$ \\
\hline $\begin{array}{l}\text { Tsurumi et al. } \\
(2015)\end{array}$ & $\begin{array}{l}\text { SPM at time of } \\
\text { survey }\end{array}$ & $\begin{array}{l}\text { Japan } 2013 \text { BLI } \\
\text { Survey. }\end{array}$ & 2,921 & $\$ 0.18$ per $\mu \mathrm{g} / \mathrm{m}^{3}$ & $\$ 0.01$ \\
\hline $\begin{array}{l}\text { Tsurumi and Managi } \\
\text { (2017) }\end{array}$ & $\begin{array}{l}\text { SPM at time of } \\
\text { survey }\end{array}$ & Japan 2013 BLI. & 2,921 & Insignificant & -- \\
\hline Liao et al. (2015) & $\begin{array}{l}\text { Percent days in June } \\
2010 \text { when local } \\
\text { pollution index } \\
\text { below "good". }\end{array}$ & Taiwan 2010 (TSCS) & 1,055 & $\begin{array}{l}\text { negative (pollution } \\
\text { increases happiness) }\end{array}$ & -- \\
\hline $\begin{array}{l}\text { Dolan and Laffan } \\
(2016)\end{array}$ & $\begin{array}{l}\text { PM2.5 (annual local } \\
\text { mean) }\end{array}$ & UK APS & $\approx 130,000$ & $\mathrm{f} 261.25$ per $\mu \mathrm{g} / \mathrm{m}^{3}$ & $\$ 170.65$ \\
\hline Glaeser et al. (2016) & PM10 & $\begin{array}{l}\text { US Cities in } 2000 \\
\text { (BRFSS) }\end{array}$ & $1,182,563$ & Insignificant & -- \\
\hline Zhang et al. (2017b) & PM2.5 & China cities 2014 & 21,589 & & $\$ 8.11$ \\
\hline \multicolumn{6}{|c|}{ Repeated Cross Sections } \\
\hline $\begin{array}{l}\text { Menz and Welsch } \\
(2010)\end{array}$ & PM10 & $\begin{array}{l}25 \text { OECD countries, } \\
1990-2004 . \text { World } \\
\text { Values Survey. }\end{array}$ & 136 & $\$ 98-\$ 185$ per $\mu \mathrm{g} / \mathrm{m}^{3}$ & $\$ 2.55-\$ 3.29$ \\
\hline Menz (2011) & $\begin{array}{l}\text { PM10 (annual mean, } \\
\text { urban population } \\
\text { weighted) }\end{array}$ & $\begin{array}{l}48 \text { countries } 1990- \\
2006\end{array}$ & 253 & $\$ 136$ per $\mu g / m^{3}$ & $\$ 11.23$ \\
\hline $\begin{array}{l}\text { Menz and Welsch } \\
\text { (2012) }\end{array}$ & $\begin{array}{l}\mathrm{SO}_{2}, \mathrm{NO}_{2} \text { (annual } \\
\text { national mean) }\end{array}$ & $\begin{array}{l}\text { Eurobarometer. } 10 \\
\text { EU countries 1990- } \\
1997 .\end{array}$ & 59,437 & $\begin{array}{l}€ 210 \text { per } \mu \mathrm{g} / \mathrm{m}^{3} \mathrm{SO}_{2} \\
€ 139 \text { per } \mu \mathrm{g} / \mathrm{m}^{3} \mathrm{NO}_{2}\end{array}$ & $\begin{array}{l}\$ 10.23\left(\mathrm{SO}_{2}\right) \\
\$ 7.25\left(\mathrm{NO}_{2}\right)\end{array}$ \\
\hline
\end{tabular}




\begin{tabular}{|c|c|c|c|c|c|}
\hline Ferreira et al. (2013) & $\begin{array}{l}\mathrm{SO}_{2} \text { (annual regional } \\
\text { means) }\end{array}$ & $\begin{array}{l}\text { ESS. } 23 \text { EU } \\
\text { countries, } 248 \\
\text { regions, 2002-2007. }\end{array}$ & $\approx 70,000$ & $€ 2,925$ per $\mu \mathrm{g} / \mathrm{m}^{3} \mathrm{SO}_{2}$ & $\$ 44.81$ \\
\hline $\begin{array}{l}\text { García-Mainar et al. } \\
\text { (2015) }\end{array}$ & $\begin{array}{l}\text { PM10 (days }>50 \\
\mu \mathrm{g} / \mathrm{m}^{3} \text { ) }\end{array}$ & $\begin{array}{l}\text { ECVT, Spain, } 17 \\
\text { regions, 2006-2010 }\end{array}$ & 32,317 & $\begin{array}{l}€ 17 \text { - €20 per one day } \\
\text { reduction }\end{array}$ & $\$ 3.69-\$ 4.35$ \\
\hline Orru et al. (2016) & PM10 & $\begin{array}{l}\text { Europe (ESS 2010, } \\
\text { 2012) }\end{array}$ & 3,770 & $\begin{array}{l}\text { Omits absolute income } \\
\text { covariate. }\end{array}$ & -- \\
\hline $\begin{array}{l}\text { Barrington-Leigh } \\
\text { and Behzadnejad } \\
\text { (2017) }\end{array}$ & $\begin{array}{l}\mathrm{SO}_{2} \text { (Daily local } \\
\text { mean) }\end{array}$ & CCHS 2005-2011 & 322,233 & $\$ 890$ per $\mu \mathrm{g} / \mathrm{m}^{3}$ & $\$ 19.99$ \\
\hline \multicolumn{6}{|l|}{ Panel data } \\
\hline Giovanis and & $\mathrm{O}_{3}, \mathrm{SO}_{2}, \mathrm{NO}_{2}, \mathrm{CO}$ & Switzerland (SHPS) & 71,804 & $\mathrm{O}_{3}: \$ 8900 \mathrm{per} \mu \mathrm{g} / \mathrm{m}^{3}$ & $\mathrm{O}_{3}: \$ 25.12$ \\
\hline \multirow[t]{4}{*}{ Ozdamar (2016) } & PM10 (annual & $2000-2013$ & & $\mathrm{SO}_{2}: \$ 11,985$ & $\mathrm{SO}_{2}: \$ 33.83$ \\
\hline & means) & & & $\mathrm{NO}_{2}: \$ 6,580$ & $\mathrm{NO}_{2}: \$ 18.57$ \\
\hline & & & & CO: $\$ 1,940$ & CO: $\$ 5.48$ \\
\hline & & & & PM10: \$2,320 & PM10: $\$ 6.55$ \\
\hline Giovanis (2017) & local average) & Panel Survey, 1991- & & $\mathrm{NO}_{\mathrm{x}}: £ 1,070$ & $\mathrm{NO}_{\mathrm{x}}: \$ 4.99$ \\
\hline & & 2009 & & CO: insignificant & CO: -- \\
\hline Zhang et al. (2017a) & API & $\begin{array}{l}\text { China Family Panel } \\
\text { Studies 2010, 2012, } \\
2014 .\end{array}$ & 49,333 & & $\$ 4.29$ \\
\hline
\end{tabular}

Pollutants: nitrous oxides $\left(\mathrm{NO}_{x}\right.$ or $\left.\mathrm{NO}_{2}\right)$, sulfur dioxide $\left(\mathrm{SO}_{2}\right)$, carbon monoxide $(\mathrm{CO})$ ozone $\left(\mathrm{O}_{3}\right)$, particulates smaller than 10 microns $(\mathrm{PM} 10)$, smaller than 2.5 microns (PM2.5) suspended particulate matter (SPM), air pollution index (API).

"Monetary values converted to 2016 \$US by first using average exchange rates, and then inflating by the CPI-U. 